\title{
Dona, pobra, mare i fadrina contra l'autoritat moral. El procés inquisitorial d'Àgueda Guimerà (1804)
}

\section{Woman, poor, mother and single against moral authority. The Inquisitorial Trial of Àgueda Guimerà (1804)}

\author{
JACOB MOMPÓ NAVARRO \\ jacob.mompo@ucv.es
}

Universitat Catòlica de València

\begin{abstract}
Resum: En 1804, el Tribunal de la Inquisició vivia els seus darrers moments. Lluny de les grans persecucions inicials contra jueus i moriscos, el Sant Ofici semblava llanguir, però sense dubte, tot i que amb menys força que en temps passats, encara era un instrument formidable de repressió. En aquest context, Àgueda Guimerà, mare soltera, i per això criticada i maltractada, va haver de fer front a una denúncia per calúmnies per part del seu confessor en què en tot moment plana la sospita del delicte de sol licitació en acte de confessió
\end{abstract}

Paraules clau: Inquisició, conducta moral, dona soltera, segle XIX, sol licitació

Abstract: In 1804, the Court of the Inquisition was living its last moments. Far from the great initial persecutions against Jews and Moors, the Holy Office seemed to languish, but certainly, although with less force than in past times, still was a formidable instrument of repression. In this context, Agueda Guimerà, a single mother, and therefore criticized and mistreated, had to face a denunciation for slander by her confessor in which the suspicion of the crime of solicitation in the act of confession was floating in the air.

Keywords: Inquisition, moral conduct, single woman, nineteenth century, solicitation

\footnotetext{
* Aquest article s'inclou en les recerques de l'equip de treball del projecte d'investigació "Biografías marginales: violencia, sexo, género e identidad. Edición y análisis de las fuentes documentales valencianas de la época foral", finançat pel Ministerio de Ciencia, Innovación y Universidades del Gobierno de España (PGC2018-097011-B-I00).
}

DATA PRESENTACIÓ: 09/10/2020 ACCEPTACIÓ: 16/10/2020 • PUBLICACIÓ: 10/12/2020 
Jacob Mompó Navarro. Dona, pobra, mare i fadrina contra l'autoritat moral. El procés inquisitorial d’Àgueda Guimerà (1804)

\section{Introducció}

Poc sabem de la protagonista d'aquest procés, més enllà del que es traspua de l'escassa documentació conservada. ${ }^{1}$ Àgueda Guimerà va viure a la localitat d'Ortells (els Ports) a finals del segle XVIII i principis del XIX i era mare soltera d'un fill que en els moments dels fets (1804) tenia poc dalt o baix dotze anys. Segons les declaracions de l'altre protagonista d'aquesta història, Felicio Esteller, el rector de l'església parroquial d'Ortells, aquell fill va ser fruit de la relació extramatrimonial que Àgueda va mantenir amb dos germans, circumstància que la convertia en una dona de conducta escandalosa, moralment reprovable; per bé que, tal com podrem comprovar, tota l'oratòria d'Esteller va encaminada a destruir qualsevol rastre d'honestedat de Guimerà. Fadrina, amb un fill i sense gaires recursos econòmics, Àgueda Guimerà devia suportar grans patiments per tal de poder tirar endavant la seua família. Del pare de la criatura no sabem res, més que devia ser algun d'aquells dos germans que, sempre segons Esteller, arran de les relacions que van mantenir amb Àgueda, van haver de fugir del poble i enrolar-se en l'exèrcit al servei de sa majestat.

Pel que fa a l'altre protagonista del succés, Felicio Esteller era el rector titular de la parròquia d'Ortells. Segurament era una persona culta, si atenem, d'una banda, a la riquesa lingüística dels texts, en castellà, de les seues cartes, malgrat les notables interferències de la seua llengua materna, el català, que hom hi aprecia. De l'altra, perquè ostentava el càrrec de notari escrivà del Sant Ofici, oficial de la institució a la qual es va adreçar reiteradament per denunciar les actituds que sobre la seua persona mostrava Àgueda. Entre els oficials que integraven el tribunal, hi havia tres notaris; el notari de segrestos, encarregats de registrar les propietats confiscades; el notari del secret, que anotava les declaracions dels testimonis, i l'escrivà general, que realitzava les funcions pròpies d'un secretari, encarregat d'enregistrar la distinta burocràcia inquisitorial (García-Cárcel 1976: 136-137). No sabem quin tipus de notari era Esteller, però podem suposar-li, doncs, una certa formació intel lectual. D’altra banda, els oficis inquisitorials eren vitalicis, $i$, per bé que les consecutives instruccions legislatives del Sant Ofici s'encaminaven a evitar el nepotisme al si de la seua estructura, el fet cert és que, moltes vegades, aquests oficis esdevenien hereditaris, i en el cas de l'ofici de notari, era l'inquisidor general l'encarregat de validar el seu nomenament, fet que ens permet situar-lo al si d'una família socialment acomodada i benestant (García-Cárcel \& Moreno Martínez 2000: 116-117). ${ }^{2}$

En aquest treball emmarcarem el procés contra Àgueda Guimerà al si dels darrers temps del Sant Ofici, donarem compte de les adversitats a què va haver de fer front, com a dona, com a mare i com a soltera, així com de les circumstàncies que portaren mossén Felicio Esteller a denunciar la seua feligresa davant el tribunal inquisitorial. Si bé és cert que la documentació conservada només

1 La documentació conservada sobre el procés contra Àgueda Guimerà, a AHN, Inquisició, lligall 5312, expedient 127. Indicarem la localització de les parts que transcrivim d'aquest procés únicament amb la foliació. Per a la localització d'altres processos, indicarem la referència completa.

2 Una imatge detallada de l'estructura inquisitorial al capítol «Estructura y política», de Kamen (2005: 136-170)

SCRIPTA, Revista internacional de literatura i cultura medieval i moderna, núm. 16 / desembre 2020 / pp. 366-382 ISSN: 2340-4841 · doi:10.7203/SCRIPTA.16.19235 
Jacob Mompó Navarro. Dona, pobra, mare i fadrina contra l'autoritat moral. El procés inquisitorial d’Àgueda Guimerà (1804)

ens ha permés tindre la visió d'una de les dues parts, la del religiós, d'entre les línies de les cartes que Esteller va enviar a la Inquisició s'ensuma quelcom que ens permet albirar les circumstàncies que propiciaren la denúncia; o, almenys, formular alguns interrogants que qüestionen la versió dels fets que recull la denúncia.

\section{Els darrers temps de la Inquisició}

S'ha escrit molt sobre els inicis de la Inquisició moderna. ${ }^{3}$ Des de la seua instauració en territoris peninsulars, el tribunal del Sant Ofici ha gaudit d'una enorme fama de crueltat, d'instrument repressiu, d'arma política magna al servei de la Monarquia hispànica. En certa manera es tractava d'això. També s'ha escrit molt, però, sobre la llegenda negra, que, en el cas concret de la Inquisició, ha fet córrer rius de tinta al llarg de l'edat moderna, però també encara avui. El Sant Ofici apareix en nombrosos estudis, també en obres literàries, com ara en novel les històriques, com una institució impermeable, obscura, violenta i, sobretot, enigmàtica. Diu Giuseppe Grilli, a propòsit de la literatura creada entorn el Vaticà i la família Borja, que:
el enigma de Roderic y de su apuesta constante en la historia y en la historiografía [...] acaba por identificarse con la obsesión perenne de cada literatura historiográfica por el enigma como paradigma (Grilli 2019: 251).

En el cas de la Inquisició, hom pot subscriure punt per punt aquesta cita, tot bescanviant el nom del cardenal valencià pel de la institució fundada per perseguir l'herètica pravitat. Però les actuacions inquisitorials s'han d'entendre en el marc històric en què es produïren. I, si bé és cert que la Inquisició era una màquina colossal de persecució contra minories dissidents, la seua implacabilitat no va ser la mateixa al llarg dels seus prop de tres-cents cinquanta anys d'existència. Ni tampoc va ser l'única. Sobra contemplar les actuacions de les diferents justícies seglars -també episcopals-per copsar que la violència, la coacció i la persecució no eren patrimoni exclusiu del Sant Ofici.

Lluny de les grans persecucions de segles anteriors -contra criptojueus, primer, i moriscos, després-, a finals del segle XVIII, el Tribunal semblava llanguir. La llarga xarxa clientelar de familiars feia temps que s'havia diluit. Efectivament, la Inquisició no tenia la mateixa força que als inicis, i havia descendit notablement el nombre de condemnats a mort. No debades, la persistència de la institució havia aconseguit, amb un èxit notori, l'extirpació de l'heretgia. Sense jueus ni moriscos, el Sant Ofici s'hagué de conformar a jutjar supersticions, sacrilegis, proposicions, blasfèmies, sol licitacions, fetilleries, així com l'eterna persecució contra la llibertat sexual dels homosexuals. Però el descens de les sentències de mort no significava que la maquinària inquisitorial continuàs funcionant com

3 Vegeu, en aquest sentit, Lea (1906-08), Turberville (1954), Pérez Villanueva (1980), Pérez Villanueva \& Escadell Bonet (1984), Bennassar (1984), Pinto Crespo (1983), Blázquez Miguel (1988), Escudero López (1983, 1986,1987 i 2005), Peters (1988), Haliczer (1990), Monter (1992) o Escudero López \& Birckel (2004). 
Jacob Mompó Navarro. Dona, pobra, mare i fadrina contra l'autoritat moral. El procés inquisitorial d’Àgueda Guimerà (1804)

un excel lent mecanisme de coerció. En aquest sentit, les circumstàncies suara exposades, per a La Parra \& Casado (2013) no demostren que la institució tinguera mala salut en la segona meitat del segle XVIII.

Més que pels problemes interns que pogués tenir el tribunal, el final de la Inquisició es va precipitar pel seu mateix context històric, perquè, per molt que havia persistit en el temps aferrada a la seua condició d'autoritat en la doctrina, fe i moral, no va poder perllongar-se més en el temps en el marc d'una societat europea on els corrents racionalistes -en uns llocs més que en altres- anaven obrint-se pas. Ara bé, encara va resistir estoicament perquè, tot i que pocs anys després dels fets que tractem en aquest article, en 1808, la Constitució bonapartista de Baiona abolia tots els tribunals amb atribucions especials, i en 1813 les Corts de Cadis l'abolien explícitament, la institució va retornar amb Ferran VII i aconseguí sobreviure fins, de factos l'any 1820, per bé que la seua abolició total no es va materialitzar fins el 15 de juliol de 1834 (Díez Morrás 2020: 302-303).

\section{Dona i mare soltera. La condició social d'Àgueda Guimerà}

Mentre l'Antic règim trontollava arreu d'Europa a les acaballes del segle XVIII, el matrimoni continuava essent una figura jurídica, però també cultural, sobre la qual es fonamentava la societat, un vincle indissoluble, idealitzat, que gaudia -i gaudeix- d'una gran popularitat (Simón Hernández 2017: 127). De fet, el temps de la fadrinesa no s'entenia sinó com una etapa de transició entre l'adolescència i la maduresa adulta que culminava amb el sagrament matrimonial. Però part de la societat, voluntàriament o no, va romandre fora del matrimoni al llarg de la seua vida. En aquests casos, el seu estatus de fadrí o fadrina deixava d'entendre's com una etapa vital per a convertir-se, gairebé, en una categoria social (Tovar-Pulido 2020: 150).

Però si la fadrinesa estava parcialment acceptada en els homes, les solteres havien de suportar les crítiques d'una societat que recelava d'una dona capaç de viure $-\mathrm{O}$, en la majoria dels casos, sobreviure- sense l'autoritat domèstica del pater familias. ${ }^{4}$ En aquest sentit, excepte aquelles dones -estadísticament, poques- procedents de famílies benestants que podien gaudir de l'administració dels béns familiars, les dones solteres dels estrats populars de la societat, sovint, havien de malviure per mantenir els fills, si en tenien. Aquestes dones socialment humils, generalment sense formació,

\footnotetext{
4 Un estudi detallat sobre la família i el matrimoni a Espanya durant el segle XVIII a partir de l'exhumació d'abundant documentació notarial a Ortego Agustín (1999). Sobre el mateix període i les dificultats de les dones solteres o amb marits absents i la gestió del patrimoni familiar, vegeu De la Pascua (2016) i Tovar-Pulido (2020). Per a la situació de les dones al llarg del segle XX resulta interessant l'estudi de Belmonte (2018). Una mirada sobre l'evolució historiogràfica de la dona a Rial Garcia (2008). Un estudi general sobre el treball de les dones rurals a l'Espanya de l'edat moderna a Rey Castelao (2015). Abunden treballs interessants sobre el món laboral femení emmarcats en territoris concrets, entre els quals destaquem, per al cas d’Almeria i Jaén, Garrido-González (2016 i 2017); per a Galícia, Rial García (2009) i Dubert (2015); per a Biscaia, Fernández \& Prado (2000) o per a la comarca de la Sierra de Alcaraz, Simón Hernández (2017); Per a la València dels segles XVII i XVIII, vegeu Baixauli (2020a i 2020b). Molt recomanable és l'estudi del fenomen concret de l'emigració de dones solteres de Canàries cap a Amèrica de Monzón Perdomo (2018).
}

SCRIPTA, Revista internacional de literatura i cultura medieval i moderna, núm. 16 / desembre 2020 / pp. 366-382 ISSN: 2340-4841 · doi:10.7203/SCRIPTA.16.19235 
Jacob Mompó Navarro. Dona, pobra, mare i fadrina contra l'autoritat moral. El procés inquisitorial d’Àgueda Guimerà (1804)

s'adaptaven com podien als temps que vivien, realitzant treballs precaris, sovint en l'àmbit domèstic, o bé tasques relacionades amb l'activitat agrícola i ramadera. D’altres, es veien abocades a la mendicitat o, pitjor encara, a la prostitució. En aquest context es produien els recels d'una societat que veia amb mals ulls les dones fadrines, $\mathrm{i}$ amb una certa enveja aquelles dones solteres que aconseguien estoicament i digna mantenir en condicions una família monoparental. Les connotacions negatives que tenia la condició de dona sola portaven, en moltes ocasions, a suposar a aquelles dones activitats moralment reprovables com la prostitució o l'amistançament.

En el marc de la marginalitat a les acaballes de l'antic règim -i encara avui-, certament, l'exercici de la prostitució era un estigma social que afectava moltes dones dels estrats humils de la societat. Durant la segona meitat del segle XVIII, proliferaren les cases de dones penedides que, malgrat que en un primer moment estaven destinades a dones provinents de les capes socialment superiors (vídues, separades o dones abandonades pel seu marit), ben aviat, les demandes de la societat per tal de regenerar la conducta reprovable de dones acusades de diversos delictes, o que exercien la prostitució, va modificar substancialment la funció d'aquests centres, que passaren a recollir dones públiques, pecadores, prostitutes, criminals, adúlteres, etc. i començaren a actuar, funcionalment, com a centres preventius, correctius i exemplificadors (Monzón Perdomo 2000b: 1750). ${ }^{5}$

Pel que fa al cas que ens pertoca, no podem afirmar que Àgueda es dedicàs a la prostitució, ni, com insinua Esteller, que cercàs l'amistançament interessat, defugint del matrimoni, o, una insinuació encara pitjor, accedir a tracte carnal amb el rector mateix a condició que, si resultava embarassada, el rector havia de mantenir econòmicament Àgueda, el seu fill i el fill resultant d'aquella còpula. Les úniques proves que aportava el rector en aquest mateix sentit radicaven en el fet que Àgueda fos mare soltera d'un fill nascut fora del matrimoni, així com tota una sèrie de suposades difamacions i amenaces que el rector no va poder demostrar; ni tan sols, com veurem, amb un curiós estratagema efectuat amb poca fortuna, propi d'un relat literari còmic. Però aquest tipus d'insinuacions, així com falses acusacions de prostitució, que es convertien en insults $\mathrm{i}$ atacs personals directes, eren $-\mathrm{i}$ malauradament, encara ho són- una pràctica habitual per a desprestigiar la conducta social d'una dona. La retòrica i l'estil de redacció de Felicio Esteller l'impedeix acudir a l'insult vulgar, però entre les cartes que el rector enviava al Tribunal de la Inquisició de València figuren adjectius com ara perversa, mundana, mentidera, de condicions reprensibles, fal laç, indecorosa, infame, calumniadora, impostora, falsària, dona sense crèdit, execrable, iniqua, horrible, loquaç, incorregible, obstinada, malvada, condescendent, escandalosa, cega, sense temor de Déu, maliciosa, insolent, murmuradora o ignominiosa, entre d'altres.

Com hem dit més amunt, solament s'ha conservat la versió de mossén Esteller, recollida en unes cartes adreçades al Tribunal de València en què el rector acusava Guimerà de difamar la seua

5 Vegeu, en aquest sentit, els treballs de Monzón Perdomo (2000a i 2000b), Sáez García (2018). Sobre les presons femenines a l'antic règim, resulta interessant Torremocha (2018). Per al cas de Catalunya, i en el marc de la infidelitat femenina, vegeu Capdeferro \& Ribalta (2014). Una visió panoràmica dels espais de reclusió femenina a Barcelona en Segura (1996). El cas concret de la casa de penedides de València, a Vidal Gavidia (2000).

SCRIPTA, Revista internacional de literatura i cultura medieval i moderna, núm. 16 / desembre 2020 / pp. 366-382 ISSN: 2340-4841 · doi:10.7203/SCRIPTA.16.19235 
Jacob Mompó Navarro. Dona, pobra, mare i fadrina contra l'autoritat moral. El procés inquisitorial d’Àgueda Guimerà (1804)

persona, d'acusar-lo de mantenir relacions amb dones casades; però, sobretot, d'oferir-li a l'acusada mateixa tracte carnal en acte de confessió. Aquest darrer punt apareix reiteradament al llarg de les cartes d'Esteller, que, tal com s'entreveu en aquelles lletres, semblen redactades de manera preventiva, davant una imminent acusació de sol licitació. Es tractava d'una lluita desigual entre una dona humil, mare soltera d'un fill fruit de relacions extramatrimonials, acusada de portar una vida moralment reprovable, contra el pare espiritual del seu poble, la màxima autoritat religiosa i membre d'una formidable institució que, malgrat trobar-se en els seus últims moments, mantenia, encara, un notable poder de coacció.

\title{
4. E1 procés contra Àgueda Guimerà
}

L’expedient que conserva la documentació del procés contra Àgueda Guimerà s’inicia amb un breu resum del seu contingut:

\author{
Valencia. Año 1804 \\ Expediente formado con motivo de dos cartas escritas por mossén Felicio Esteller, cura \\ párroco del lugar de Ortells, y ministro notario del Santo Oficio, sobre haber propagado \\ contra él varias calumnias Águeda Guimerà, vecina del mismo (f. 1r).
}

Aquest expedient, en realitat, està format per tres cartes d'Esteller, per bé que la segona és una còpia, amb poques variants, de la primera, més les diligències efectuades pel tinent d'agutzil major de Morella, Antoni Colomer. Com hem dit adés, Esteller, notari de la Inquisició i rector de l'església parroquial d'Ortells, es va veure en la necessitat d'adreçar una carta al Tribunal de la Inquisició de València. Sembla, segons les paraules d'Esteller, que la veïna d'Ortells el va difamar de moltes i variades maneres. De tal manera que, segons sembla, l'honorabilitat i la fama del rector entre els seus feligresos estava en perill. La seua condició de notari de la Inquisició propiciava que qualsevol judici en què es veiés involucrat s'havia de resoldre mitjançant el fur inquisitorial. ${ }^{6}$ En altres paraules, en aquest cas concret, difamar un membre del tribunal era una ofensa al tribunal mateix, i aquest havia de ser l'encarregat de jutjar els fets. Però, com de greus eres aquelles ofenses com perquè el religiós incoara el procés contra Guimerà? Si són certes les afirmacions del rector, certament, gravíssimes. Àgueda l'acusava de mantenir relacions amb dues dones casades de la localitat, també d'efectuar estranys rituals amb què li transmetia el dimoni amb l'alé; però, sobretot, de cometre el delicte de sol licitació, atemptat sacríleg contra el sagrament de la confessió. Així doncs l'1, de febrer de 1804, mossén Esteller iniciava la redacció de la seua primera carta:

6 Fins i tot en plets i disputes per propietats agrícoles, només que un dels dos litigants fora familiar de la Inquisició, el judici s'havia de resoldre pel tribunal inquisitorial. Vegeu, a tall d'exemple, el plet ventilat en el Tribunal de la Inquisició de València entre Ignaci i Blas Boscà, fills d’un familiar de la Inquisició, contra Josep Antoni Llinàs -tots els litigants de la Pobla de Rugat (la Pobla del Duc) - per una escriptura de retroventa que afectava un minúscul camp de conreu (AHN, Inquisició, llig. 1778, exp. 7). 
Jacob Mompó Navarro. Dona, pobra, mare i fadrina contra l'autoritat moral. El procés inquisitorial d'Àgueda Guimerà (1804)

Muy ilustres señores,

Don Felicio Esteller, rector de la parroquial iglesia del lugar de Ortells, reyno de Valencia, obispado de Tortosa, con el mayor respeto y modo le sea permitido, ante vuestras señorías dice que está sufriendo, con la mayor infamia y falsedad, la más horrible calumnia por una perversa muger, llamada Àgueda Guimerà, de ésta, mi feligresía, moza de estado, pero mundana, según se dexa ver de los efectos. Pues es público y notorio que en dicho estado de moza tuvo un hijo haze unos dose años por haver tenido cópula carnal con dos hermanos, por cuyo echo, los dichos hermanos fueron destinados al servicio del rey.

Esteller encetava la seua argumentació atacant directament l'honorabilitat d'Àgueda, per la seua condició de dona fadrina, amb un fill fruit de les relacions que mantenia fora del matrimoni. Notem, però, que els dos germans, igualment culpables de tracte carnal fora de la institució del matrimoni, són vistos pel rector com a víctimes d'una dona perversa. Però la carta continuava sacsejant l'honor de la dona mitjançant la redacció de huit capítols:

Muger mentirosa y de condiciones reprencibles:

Esta falaz muger (a mi entender, y con noticia de tercero), falsamente persuadida de que mi proceder (en el Tribunal de la Penitencia) con ella, o contra ella, lo era porque ciertos sujetos me daban noticia de su conducta, lo que es absolutamente falso; ésta, pues, á venido a destenerse con la lengua contra mí y contra los dichos sujetos; de modo que en ella no hai reserva, antes bien se ha valido de los puntos más indecorosos con que le ha parecido podría infamarnos. $\mathrm{Y}$ es en los términos siguientes:

Primeramente: La referida Àgueda Guimerà dixo que yo le he dado los demonios o malignos (propio término que husó ella) y que se los di en el confecionario, y con el aliento.

$2^{\circ}$ : Dixo que yo la é solicitado ad venerea en el confesionario. De esto la falsedad se deduce de que después de haberse confesado conmigo, al cabo de rato, día o días, lo que no tengo presente, la dicha calumniante me embió un recado por una muger de las más honradas del pueblo, diciéndome que ella (que es la referida Àgueda Guimerà) ni hazía la vida de santa María Magdalena ni la de san Pedro; de cuyas palabras no se puede inferir sino que yo le daba buenos consejos y le encargaba la imitación de las virtudes de dichos santos.

$3^{\circ}$ : Dixo que yo havía tenido cópula carnal con dos mugeres casadas, nombradas por su nombre, y que con especialidad, con la una de éstas, han sido tantos los concúbitos que é tenido que no se puede decir el número; que dichos concúbitos los é tenido en casa de la supuesta adulterada y en mi casa. Y dice la impostora muger que yo se lo é dicho, y que se lo é dicho en el confesionario, que es en donde, dice, solicite a ella. Y asegura ésta que ella convino en mi solicitación, pero con la condición de que, si ella quedaba embarazada, havía yo de mantener a dicha calumniante, a la prole que resultase y al antemencionado hijo suyo natural. Y que los havía de mantener y tener a todos tres en mi casa. De donde podrán inferir, vuestras señorías, la seguedad de la calumniante, y más si vuestras señorías supiesen mi decoro es este pueblo y circumvecinos, y la falta de esto en la falsaria; pues por no tener crédito la dicha calumniante, havia asegurado dichos falsos echos y calumnias con juramentos execratorios contra ella, como son decir que la tierra se abra y los demonios la lleven si no es verdad; y que es cierto lo que dice, y que dice lo mismo haunque fuera en medio de la plaza, haunque en acabando la huviesen de echar en una oguera. $Y$ con esto, no la quieren creer, manifestándose la que escuchava estos improperios, temerosa per las execraciones que profería la dicha Àgueda esto dixo: «no temas, que yo te sacaré o libraré de todo». Replicola la muger que esto 
Jacob Mompó Navarro. Dona, pobra, mare i fadrina contra l'autoritat moral. El procés inquisitorial d’Àgueda Guimerà (1804)

escuchava diciendo: «Mira que esas son cosas de Ynquisición», a que respondió la enunciada Àgueda Guimerà, impostora,: «Si fuéramos a la Ynquisición, él (que soy yo) se quedaría en la Ynquisición y yo libre a mi casa me bolvería» (ff. 2r-2v).

No és estrany que mossén Felicio Esteller intentàs dinamitar la credibilitat d'Àgueda Guimerà, tenint en compte que, si era cert el que afirmava el rector, Guimerà tenia la intenció de denunciar-lo al tribunal inquisitorial per delictes de sol licitació. D’aquesta manera, tant si Esteller era culpable com si les paraules d'Àgueda eren, efectivament, difamacions sense fonament, amb aquesta carta el mossén movia peces estratègiques per neutralitzar aquella suposada i imminent denúncia. Insinuada, doncs, la causa de la possible denúncia que Àgueda podia imputar-li, Esteller continuava atacant la dona:

\begin{abstract}
$4^{\circ}$ : Dixo que quando careaceo en la iglesia (que lo ago con freqüencia a causa del destilo que padesco), lo ago por ella, que estoy enamorado de ella y ella de mí.

$5^{\circ}$ : Haviéndome encargado de predicar un sermón a honra de san Antonio Abad en su día próximo pasado, en un lugar llamado Villores, dixo la iniqua muger que yo le havía dicho que viniese a dicho lugar el día que predicara, que se pusiese enfrente del púlpito de donde yo la pudiera ver, y que de quando en quando, levantara el delantal. Son tantos los enredos que dicha muger á propuesto, que sería menester formar un grande volumen. En una palabra: quanto le viene a la boca, y ni siquiera hai una verdad.

$6^{\circ}$ : Dixo que no solo la solicité en el confesionario, sino que también en mi casa.

$7^{\circ}$ : Dixo que ella se confesaría con otro y después vendría a mí. Y si le preguntava quanto tiempo que no se havía confesado, respondería «de quando me confesé con usté». Y diciéndole [a] la que esto escuchava: «muger, que harías buena confesión entrando mintiendo», respondió la calumniante: «¿Pues, que yo le é de decir mis miserias? Que suba aquí y verá a su abuela», haciendo al mismo tiempo la acción que suelen llamar "haser tantos".

$8^{\circ}$ : En fin, dexando otras muchas cosas que la dicha impostora á dicho, que haunque no son en sí malas, pero por ser mentiras podrían más y más acreditar la falsedad de las calumnias y maldades que me atribuie, pero por no ser prolixo las omito; las que si fuere necesario diré y explicaré (ff. 2v-3r).
\end{abstract}

Veiem que Esteller tornava a incidir en el delicte de sol licitació que li atribuïa Guimerà, fet que el rector intentava neutralitzar una vegada i una altra. I al voltant d'aquest tema nuclear, afegia altres circumstàncies que Guimerà pogués eximir en la seua particular acusació, com ara l'escena més o menys curiosa, gairebé còmica, d'Esteller sermonejant darrere del púlpit mentre Àgueda li mostrava allò que cobria el davantal. La carta prossegueix amb el curiós artifici que va fer servir el rector per a desemmascarar la suposada impostora, una diligència que, segons la narració del religiós, no degué funcionar com ell esperava:

Y así solo devo añadir que, por temeroso de que la falsa muger negase lo que havia dicho delante de solas mugeres, como hasí lo á hecho, pensé de haser la diligencia siguiente:

Día veinte de enero de este año mil ochocientos y quatro encargué a Joseph Martí, entonces alcalde orinario de este pueblo, para que llamase dos hombres y los tuviese ocultos en parage en que, llamada la dicha Àgueda Guimerà y preguntada de las cosas que decía o havía dicho de 
Jacob Mompó Navarro. Dona, pobra, mare i fadrina contra l'autoritat moral. El procés inquisitorial d’Àgueda Guimerà (1804)

\begin{abstract}
mí y de las mugeres con quienes me acomula los adulterios, lo vieran para si fuese necesario. Y haviéndolo así verificado, negó el haver dicho cosa alguna de con las mugeres; y afirmó ser verdad el haverla solicitado en el confesionario, y casi todas las cosas que dice haverle dicho yo, propone que se las he dicho en el confesionario, persuadida de que yo de esto no le podré provar nada; y que bastarán sus dichos para ser creida y perderme; pues así lo dixo a Josepha Barreda, vesina de este pueblo, que reprendiéndola ésta porque le decía que yo le havía dado los demonios, o malignos, entre otras cosas, dixo que havía de perder a dos o tres (f. $3 \mathrm{v}$ ).
\end{abstract}

Si el propòsit del rector era que Guimerà admetera que l'havia difamat amb falsedats mentre uns homes romanien ajupits en aquell paratge, no ho va aconseguir. És cert que va negar haver dit res que tingués a veure amb Esteller i les dones adúlteres, però, malgrat creure's lliure d'oïts curiosos, Àgueda reafirmava les acusacions de sol licitació envers el seu pare espiritual. Per què Àgueda retreia a Felicio que l'hagués sol licitada en confessió si, tal com havia planejat Esteller, la dona creia que estaven tots dos sols? Sembla estrany que en una conversa íntima algú atribuesca a l'altre quelcom que tots dos saben que no és cert. En qualsevol cas, Esteller seguia redactant en aquella primera carta un paràgraf de justificació explicant, poc dalt o baix, que si ell fos culpable de qualsevol delicte, especialment del de sol licitació, ell mateix seria el primer a comunicar-ho al Tribunal:

\begin{abstract}
Esto es lo que se me ofrece manifestar a vuestras señorías a fin de evitar los escándalos que de estas falsedades se han de seguir en mis feligreses y de quantos lleguen a tener noticia de estas cosas si no es castigada con el rigor que merese un tan horrible atrevimiento en calumniar a un sacerdote de crímenes tan indecorosos, no solo a la persona, si<no $>$ que tambien al estado y al sacramento, motivando horror a los ministros de la Penitencia. Jurando a Dios nuestro señor ser falso quanto se me imputa, y que si tuviese conosimiento de haver delinquido en alguna cosa, y con especialidad de solicitación, yo mismo lo declararía ante vuestras señorías con la mayor humildad.
\end{abstract}

I acabava aquella carta proposant al tribunal una altra curiosa diligència. En aquest cas, oferir a la Inquisició una llista de persones de suposada credibilitat que testificarien a favor d'ell, tot exceptuant d'aquella llista els familiars d'Àgueda. Així, segons l'oferiment del rector, aquest tenia la possibilitat de comptar amb el testimoni de gent propera a ell i, en canvi, l'acusada, no:

Y en prueva de mi inocencia de quanto me acrimina la referida infame muger, ofresco formar una lista de todos mis feligreses que comulgan, y dexar en libertad de vuestras señorías para que elixan los que quieran para que digan si a alguno o a alguna, en el confesionario, a tiempo de estar para oir de confesiones, é usado de la más mínima chanza ni haver sombra de ello; exceptuando para esto a la dicha calumniante, a Juan Tallada y sus domésticos, por parientes y fáciles en el ablar, de quienes, a no ver lo que pasa, haún no me reselaría. Y puede ser que, de los que yo confío, en este particular me séan falsos; pero para prueva de la seguridad que tengo, así lo ofresco, salvo en todo el mejor parecer de vustras señorías, por quienes queda rogando a Dios, prospere en lo espiritual y temporal este mínimo capellán,

Ortells y febrero a 1 de 1804 (ff. 3v-3r).

don Felicio Esteller, rector.

SCRIPTA, Revista internacional de literatura i cultura medieval i moderna, núm. 16 / desembre 2020 / pp. 366-382 ISSN: 2340-4841 · doi:10.7203/SCRIPTA.16.19235 
Jacob Mompó Navarro. Dona, pobra, mare i fadrina contra l'autoritat moral. El procés inquisitorial d'Àgueda Guimerà (1804)

Després d'aquella carta, van passar poc més de dos mesos sense que el capellà d'Ortells rebés cap resposta per part del Tribunal de València. En aquestes circumstàncies, el 8 d'abril de 1804, el rector va remetre una còpia d'aquesta missiva, no sense abans insistir en la necessitat de castigar un comportament tan greu com el d'Àgueda, que no solament atemptava contra la seua persona, sinó també contra l'estament eclesiàstic i el Ministeri de la confessió:

\begin{abstract}
Muy ilustres señores ${ }^{7}$
Don Felicio Esteller, rector de la parroquial iglesia del lugar de Ortells, ante vuestras señorías, como me sea permitido, digo: que para ocurrir a los absurdos y calumnias que los malignantes y faltos de temor de Dios pueden atribuir a los ministros del sacramento de la Penitencia, por la inflexible obligación del sigilo sacramental, con motivo de haverlo sido (por una malvada muger) mi honor, y conmigo todo el estado eclesiástico y Ministerio de confesores, porque con sus dichos acredita cosas que desdicen al estado sacerdotal. Y si esta falsa loquás muger, incorregible y obstinada, por condesendencia se dexa sin el castigo merecido a los crímenes calumniosos que me atribuie, seran sus falsedades motivo de escándalo a los ignorantes y bien intencionados, quienes presencian que, si esto hasen los eclesiásticos, es falso lo que se predica; y, por consiguiente, se arrojarán a la maldad con desprecio de la virtud. Por lo que, en vista del ningún efecto de una carta de aviso que en fecha 1 de febrero del año 1804 dirigí a vuestras señorías a fin de enterarles del suceso (estraño), para que ese Santo Tribunal disponga lo conveniente aserca de sus diferentes capítulos que contenía, por si acaso no á llegado a ese Tribunal por desvío del correo o otra causa, y viendo que dicha calumniante aún persiste en publicar y acreditar ser verdaderas las calumnias que me impuso, tal vez porque ignora que yo he echo esta diligencia, pues yo a nadie é manifestado el haver acudido a este tribunal, esperando de vustras señorías la consqüencia, por cuyos motivos repito el suceso, que lo es del tenor siguiente para instruirles (f. 4r).
\end{abstract}

Obviarem ací la còpia de la primera carta, que no conté diferències substancials respecte de l'original ni, per tant, aporta nova informació. ${ }^{8}$ Però Felicio aprofità l'enviament de la còpia per afegir que la incorregible Àgueda Guimerà persisteix a calumniar el seu pare espiritual:

Esto es lo que contenía la antes referida carta de aviso. Y ahora, viendo el descaro de la incorregible muger, que, siega y sin temor de Dios, no repara ni se contiene de repetir en sus conversaciones las antedichas inposturas para así acreditar sus dichos, con ignominia de mi honor, que por lo mismo, descaeciendo mi ánimo, parece me hiciera desente el haver de subir al púlpito a reprender los mismos desórdenes que se me imputan a no considerarme inocente. Por lo que a vuestras señorías pido y suplico, busquen y pongan a estos exesos el remedio que les paresca más conveniente, que así lo espero de su esmero a favor de la religión cathólica. Dios guarde a vuestras señorías,

Ortells y abril a 8 de 1804 (f. 5v).

Mosén Felicio Esteller, rector,

7 Al marge esquerra: Recibida en 17 de abril de 1804. Firmado, Bertrán Acedo.

8 La copia de la primera carta, als folis 4r-5v.

SCRIPTA, Revista internacional de literatura i cultura medieval i moderna, núm. 16 / desembre 2020 / pp. 366-382 ISSN: 2340-4841 · doi:10.7203/SCRIPTA.16.19235 
Jacob Mompó Navarro. Dona, pobra, mare i fadrina contra l'autoritat moral. El procés inquisitorial d’Àgueda Guimerà (1804)

El 17 d'abril de 1804, el tribunal de la Inquisició ordenà a Antoni Colomer, agutzil major de Morella, que iniciàs les diligències per tal de comprovar la veracitat de la primera carta que el rector i notari inquisitorial havia enviat a València:

Remítase la carta antecedente a don Antonio Colomer, alguacil mayor de Morella, a donde pertenece el pueblo de Ortells, a fin de que, enterado de su contenido, tome reservadamente seguros informes sobre la certeza de los hechos que se exponen, y sobre las circunstancias y concepto en que esté tenido el cura párroco que la firma y la Águeda Guimerá, supuesta propaladora y falsa calumniadora del susodicho, con todo lo demás que pueda servir de gobierno al Tribunal (f. 6r).

La lentitud del correu, que dificultava l'agilitat de les diligències que s'havien de practicar, però sobretot la pressa del religiós per ventilar aquell assumpte el van dur a redactar una tercera carta, el 2 de juliol de 1804, en què es queixava de la contumàcia d’Àgueda Guimerà i insistia que s'havien de prendre mesures que li serviren d'escarment. Aquestes presses devien estar motivades per una nova amenaça de denúncia per sol licitació davant de la Inquisició que s'entreveu en les línies següents i que es va produir just el dia anterior a la redacció de la tercera carta:

Don Felicio Esteller, presbítero rector de la iglésia parroquial del lugar de Ortells, reyno de Valencia, con la mayor sumición ante vuestras señorías, rendidamente dice:

Que haviendo avisado a vuestras señorías por dos vezes de las insolentes y graves calumnias que por Águeda Guimerà (moza de ésta, mi feligresía y vecindario de Ortells) se me imponen, y no haver experimentado ni enmienda en la maliciosa muger ni castigo alguno por sus desórdenes que tan merecido tiene, pues que sin embargo de haver tenido la enunciada diferentes correcciones y avisos, ni por eso se á contenido, procurando desonrrarme con calumnias en otras ocasiones a vuestras señorías denunciadas en qualquier parte que bien le viene. Y no solo esto, sino que en el dia de aier, primero del que rige, después de haverme dado muestras de venir a confesarse, la mencionada Águeda, en el mismo acto y confecionario, me dijo que ella no venía a confesarse, sino a contarme lo que le pasava, lo que no quise escuchar. Pero en la misma ocación, porque reprendía su procedimiento por las noticias que extra confecionem tenía, me insultó diciendo que ella lo que quería era que yo deduxera en Justicia las calumnias que me á impuesto; por lo que, despidiéndola y mandarla no se me asercara ia al confesionario, respondió que haunque yo no quiciera, que ella vendría, motivo para despacientar al más pacífico. De modo que, por esto y lo demás que les tengo comunicado, me veo precisado a repetir esta diligencia para ver si se podrán evitar a más de los escándalos, mi deshonor, castigándola con aquellas penas que correspondan a delictos de impociciones tan enormes, como calumnias. Pues son muy freqüentes las murmuraciones que de sus dichos y echos escandalosos se originan en este pueblo y, tal vez, fuera de él.

Pues haunque concidero la madura reflección con que ese Santo Tribunal mira las cosas de su cargo, y que para el acierto se nesesita de tiempo, con todo, qualquiera leve dilación es gravemente dañosa por dichos escándalos, y las impaciencias que ocaciona a los demás que supone ser cómplices en los falsos delictos que me atribuie, como también a otros a quines á tomado en ojeriza la sobredicha infame muger. Por lo que pido humildemente a vuestras 
Jacob Mompó Navarro. Dona, pobra, mare i fadrina contra l'autoritat moral. El procés inquisitorial d’Àgueda Guimerà (1804)

señorías se dignen, con piadoso corazón, resolver lo que sea más conveniente para honra de Dios y bien de las almas. Así lo expreso del recto espíritu de ese Santo Tribunal, que Dios le conserve, ruega este mínimo ministro notario de ese Santo Oficio.

Don Felicio Esteller, rector.

Ortells 2 de julio año 1804 (ff. $7 \mathrm{r}-7 \mathrm{v}$ ).

Poc després d'aquesta tercera carta, el 13 de juliol de 1804, l'agutzil Antoni Colomer ja havia recopilat totes les dades necessàries per a despatxar l'afer. Abans del seu informe, però, excusava la demora adduint que, com que tant Ortells com els pobles dels voltants eren molt menuts, se li feia complicat realitzar les investigacions i, alhora, mantenir el secret que tota investigació inquisitorial demanava. Ara bé, la carta de Colomer resulta un elogi al religiós i un atac a Guimerà, un atac a l'honorabilitat de la dona tot resumint els mateixos arguments que havia fet servir Esteller i incidint, sobretot, en la condició de mare soltera d'un fill fruit d'una relació extramatrimonial com a arma de desprestigi principal contra la persona d’Àgueda Guimerà:

\footnotetext{
Muy ilustre señoría

Para desempeñar el cometido de vuestra señoría, con la posible seguridad y reserva he tomado los informes oportunos sobre la conducta de mosén Felicio Esteller y de Águeda Guimerá, assí en Ortells, su domicilio, como en otros pueblos circunvecinos, todos de corto vecindario y, por consiguiente, muy expuesto a traslucirte qualquiera diligencia, por lo que me ha sido indispensable gastar mucho tiempo en la indagación.

De ella ha resultado que el cura Esteller es un eclesiástico de vida exemplar, sin que se le haya conocido trato alguno, siquiera levemente sospechoso, ni entrada en casa alguna del lugar, fuera de lo que exige su ministerio, cuyo exacto desempeño le ha granjeado el mayor concepto y veneración de sus feligreses y general estimación de quantos le conocen, asegurándome algunos que le trataron de joven y estudiante, no haberle notado una ligera sombra de incontinencia. Y, por el contrario, la Águeda Guimerá es tan disoluta y abandonada que, ahún siendo soltera ha llegado a correr ilícitamente con dos hermanos a un mismo tiempo, de cuyo trato resultó un hijo que ha criado públicamente y tiene en su compañía, manteniéndose soltera.

Se me ha asegurado también que la Guimerà solicitó entrar a servir de criada en la casa del referido cura, y que éste no la quiso admitir, sin duda por constarle su parte escandalosa. Y es muy presumible, atendiendo el carácter de aquella, que, resentida, de esta justa repulsa, haya querido vengarse con las calumnias que la carta expresa, y se han difundido muy poco en aquel lugar, pues ninguno de los sugetos de que me he valido me ha dicho cosa alguna en razón de ellas.

Esto es lo que he podido averiguar sobre lo contenido en la carta de vuestra señoría y la del cura, que debuelvo.

Nuestro Señor guarde a vuestra señoría muchos años.

Morella y julio, 13 de 1804 (ff. 9r-10r).
}

Tractant-se, doncs, de les paraules d'un rector i notari de la inquisició contra les d'una dona pobra, de posició dèbil i mal vista en la societat del seu temps pel fet de mantenir, amb major o menor fortuna, una família monoparental, el fiscal de la Inquisició no va haver de molestar-se a investigar més enllà del que indicaven les cartes del rector i les investigacions de l'agutzil. Així, 
Jacob Mompó Navarro. Dona, pobra, mare i fadrina contra l'autoritat moral. El procés inquisitorial d’Àgueda Guimerà (1804)

el 10 de setembre de 1804, el fiscal redactava la seua proposta de condemna, que suposava una amonestació a Guimerà així com l'amenaça de futures i més greus conseqüències si no canviava l'actitud:

El inquisidor que hace de fiscal ha visto las exposiciones que ha dirigido y repetido mosén Felicio Esteller, rector de el lugar de Ortells, contra Águeda Guimerá, vecina del mismo pueblo; y lo que ha informado don Antonio Colomer, teniente de alguacil mayor en la villa de Morella. Y es de parecer que se encargue a éste que, haciendo comparecer ante si a dicha Águeda Guimerá, la prevenga de orden del Tribunal, se abstenga de proferir expresiones insolentes y calumniosas contra dicho rector, y que le trate con el respeto debido, pues de lo contrario se tomará seria providencia. Haciendo saber al referido Esteller que, si no advirtiere enmienda en la referida muger en quanto a lo que le han motivado sus quejas, acuda al tribunal formalizándola según corresponda para administrar justicia. Vuestra señoría acordará lo más justo.

Secreto de la Inquisición de Valencia y septiembre 10 de 1804 (ff. 11r-11v).

L'inquisidor de València, el mateix dia, va acceptar la proposta del fiscal i va ordenar, en termes similars, aquesta amonestació i amenaça, afegint, però, que era deure de Guimerà donar a mossén Felicio Esteller alguna satisfacció:

\begin{abstract}
Y vistos por dicho señor inquisidor don Mathías Bertrán, que asistía solo en su audiencia de la mañana del día diez de septiembre de mil ochocientos y quatro.

Dixo: que el theniente alguacil mayor de Morella haga entender a Águeda Guimerá que, si tiene alguna quexa contra su curra párroco, la ponga dentro de un breve término y con la formalidad que corresponde con este Tribunal, o que guarde perpetuo silencio, pues en caso de no abstenerse de amenazar y molestarle, se procederá contra ella como rea injuriante de un ministro suyo, y siendo necesario, se la mandará venir presa. Y que será muy conforme que procure dar al dicho mosén Felicio alguna satisfacción, porque el Tribunal mirará siempre por su honor y estimación. Así lo mandó [12r] y rubricó dicho señor inquisidor, de que certifico. Don Francisco Cachurro, secretario (ff, 11v-12r).
\end{abstract}

La inquisició, per tant, en aquella ocasió no va deixar de banda els seus i va admetre com a certes totes les acusacions del rector d'Ortells. Àgueda quedaria, doncs, amonestada perquè no es repetiren les seues difamacions contra Esteller, en cas contrari, la sentència seria una altra més greu. Però no sabem si aquesta amonestació es va fer efectiva o no. En aquest sentit, el darrer document que conserva l'expedient és una carta de l'agutzil Colomer expressant la impossibilitat d'haver efectuat la diligència perquè Àgueda Guimerà havia abandonat la localitat d'Ortells:

No he podido poner aún en execución el cometido de vuestra señoría por habérseme informado con seguridad que el sugeto contra quien se dirigía no se halla mucho tiempo ha en el pueblo de su domicilio; si bien suele presentarse en él algunas veces y vuelve a marchar a los dos o tres días de haber estado allí. Con este motivo he prevenido con la debida reserva que se 
Jacob Mompó Navarro. Dona, pobra, mare i fadrina contra l'autoritat moral. El procés inquisitorial d'Àgueda Guimerà (1804)

me de aviso luego que llegue para dexar practicadas las diligencias que vuestra señoría se sirve prevenirme, lo que pongo en conocimiento de su señoría en cumplimiento de mi obligación.

Nuestro Señor guarde a vuestra señoría muchos años.

Morella, 10 de octubre de 1804 (f. 10r).

El cas d’Àgueda no és únic, però sí que és representatiu de la mentalitat que la societat tenia -i encara, en certa manera, té- envers la dona. L'heterodòxia que suposava mantenir un fill fruit d'una relació extramatrimonial des de la seua condició de soltera era quelcom que no cabia en els marcs mentals dels seus veïns. De fet, aquesta particularitat és la que sempre es repeteix al llarg del procés; era la forma fàcil de demostrar la falta d'honestedat de Guimerà. Però en les cartes d'Esteller s'ensuma que, probablement, no tot el que s'hi expressava era cert, o almenys deixa en l'aire un interrogant: Realment Esteller va sol licitar a Guimerà favors sexuals en acte de confessió? Certament, no ho podem assegurar. Però si les suposades difamacions d’Àgueda no fossen tal, sinó certeses, la millor arma de què hauria pogut disposar Esteller hauria sigut enviar una carta al Tribunal que posàs de manifest una suposada condició de dona moralment reprovable en la seua denunciant i poder contrarestar així l'efecte d'una possible acusació de sol licitació. I, de passada, convertir la víctima en acusada. 
Jacob Mompó Navarro. Dona, pobra, mare i fadrina contra l'autoritat moral. El procés inquisitorial d'Àgueda Guimerà (1804)

\section{Bibliografia}

Baixauli Juan, I. (2020a): El treball domèstic femení a la València del segle XVII, València: Institució Alfons el Magnànim.

- (2020b): «La mirada dels altres. El treball domèstic femení a la València dels segles XVIIXVIII», V. J. Escartí (ed.), Identitats i violències. Documentació i literatura, Catarroja: Afers [en premsa].

Belmonte Rives, P. (2018): Sobre la situación de las mujeres en españa (1800-1930). Un ejercicio de microhistoria, (Tesi doctoral), Elx: Universidad Miguel Hernández - Departament de Ciències Socials i Humanes.

Capdeferro, J. \& Ribalta, J. (2014): Banyuts catalans: l'adulteri i la Casa de les Egipcíaques a la Barcelona moderna, Barcelona: Universitat Pompeu Fabra.

De La Pascua, M. J. (2016): «“A la Sombra” de hombres ausentes: Mujeres malcasadas en el mundo hispánico del setecientos», Studia Historica, Historia Moderna, 38/2, pp. 237-285.

Díez Morrás, F. J. (2020): «Hacia el final de la inquisición en españa: el cierre del Tribunal de Logroño en 1820», Historia Constitucional, 21, pp. 300-319.

Dubert, I. (2015): «Ilegitimidad, matrimonio y mercados de trabajo femeninos en la Galicia interior, 1570-1899», Obradoiro de Historia Moderna, 24, pp. 49-86.

Escudero López, J. A. (1983) «Los orígenes del Consejo de la Suprema Inquisición», Anuario de bistoria del derecho español, 53, pp. 238-289.

-.(1986) «La Inquisición española», Historia 16, no Extra 1, pp. 5-14.

—. (1987) «Inquisición y estudios inquisitoriales», Cuenta y razón, 26, pp. 53-62.

—. (2005) Estudios sobre la Inquisición. Madrid: Marcial Pons.

Escudero, J. A. \& Birckel, M. (2004) La Inquisición. Las Rozas: Dastin Export.

Fernández, M. J. \& Prado, A. I. (2000): «Roles femeninos en la Bizkaia del siglo XIX: aproximación a la situación de la mujer en el mundo laboral en ámbitos pesqueros urbanos», Itsas Memoria. Revista de estudios maritimos del Pais Vasco, 3, pp. 277-287.

García Cárcel, R. (1976): Orígenes de la Inquisición española. El Tribunal de Valencia, 1478-1530. Barcelona: Península.

García Cárcel, R. \& Moreno Martínez, D. (2000): Inquisición. Historia crítica, Madrid: Temas de hoy.

García González, F. (2019): «Mujer, hogar y economía familiar. Desigualdad y adaptación en la sierra de Alcaraz a mediados del siglo XVIII», Hispania, 57/195, pp. 115-195.

Garrido-González, L. (2016): «La tasa de actividad femenina en el siglo XVIII en dos municipios andaluces: Laujar de Andarax (Almería) y Úbeda (Jaén)», Investigaciones de Historia Economica, 12/3, pp. 144-153.

SCRIPTA, Revista internacional de literatura i cultura medieval i moderna, núm. 16 / desembre 2020 / pp. 366-382 ISSN: 2340-4841 · doi:10.7203/SCRIPTA.16.19235 
Jacob Mompó Navarro. Dona, pobra, mare i fadrina contra l'autoritat moral. El procés inquisitorial d’Àgueda Guimerà (1804)

Garrido-González, L.(2017): «El trabajo remunerado de la mujer en el siglo XVIII. Los casos de los contratos femeninos en la industria textil de Andalucia (España), de Laujar de Andarax (Almería) y Úbeda (Jaén)», BMC Public Health, en línia: http://portal.amelica.org/ameli/ jatsRepo $/ 76 / 76691001 / \mathrm{html} /$ index.html.

Grilli, G. (2019): Perpetuum Mobile. La permanència del mito en las modernidades, Roma: Tab edizioni.

Haliczer, S. (1990) Inquisition and society in the Kingdom of Valencia, 1478-1834. Berkeley - Los Ángeles: University of California Press.

Kamen, H. (2005): La Inquisición española, Barcelona: Crítica.

La Parra, E. \& M. A. (2013): El final de la inquisicion: un sintoma de las debilidades de la ilustracion y del liberalismo en España, Madrid: Libros de la Catarata.

Lea, H. Ch. (1906-1908): A bistory of the Inquisition of Spain. 4 vols. New York - London: The Macmillan Company.

Monter, W. (1992): La otra Inquisición. Inquisición española en la Corona de Aragón, Navarra, el País Vasco y Sicilia, Barcelona: Crítica.

Monzón Perdomo, M. E. (2000): «El reconocimiento de mujeres a finales del siglo XVIII. La casa de mujeres arrepentidas de Las Palmas (Estudio estadístico)», XIV Coloquio de Historia Canario Americana, Las Palmas de Gran Canaria: Cabildo Insular de Gran Canaria, pp. 1748-1762.

_. (2018): «"Mujeres solas”. Luces y sombras de la emigración canaria a América (Siglos XVIIIXIX)», Anuario de Estudios Atlánticos, 65, pp. 1-24.

- (2000b): «El reconocimiento de mujeres a finales del siglo XVIII. La casa de mujeres arrepentidas de Las Palmas (Estudio estadístico)», XIV Coloquio de Historia Canario Americana, Las Palmas de Gran Canaria: Cabildo Insular de Gran Canaria, pp. 1748-1762.

(2000a): «La prostitución femenina en Canarias en el Antiguo Régimen. Instituciones de recogimiento». XIII Coloquio Canario-Americana. VII Congreso Internacional de Historia de América (1988). Las Palmas de Gran Canaria: Cabildo Insular de Gran Canaria, pp. 1305-1329.

Ortego Agustín, M. A. (1999): Familia y matrimonio en la España del siglo XVIII: ordenamiento jurídico y situación real de las mujeres a través de la documentación notarial, (Tesi doctoral), Madrid: Universidad Complutense de Madrid - Departamento de Historia Moderna.

Pérez Villanueva, J. (dir.) (1980) La Inquisición española. Nueva visión, nuevos horizontes. I Simposium Internacional sobre la Inquisición Española (Cuenca, 25-29 de septiembre de 1978). Madrid: Siglo XXI.

Pérez Villanueva, J. \& Escadell Bonet, B. (dirs.) (1984): Historia de la Inquisición en España y América. 3 vols. Madrid: Biblioteca de Autores Cristianos - Centro de Estudios Inquisitoriales.

Peters, E. (1988) Inquisition. Berkeley - Los Ángeles: University of California Press.

Pinto Crespo, V. (1983) Inquisición y control ideológico en la España del siglo XVI. Madrid: Taurus.

SCRIPTA, Revista internacional de literatura i cultura medieval i moderna, núm. 16 / desembre 2020 / pp. 366-382 ISSN: 2340-4841 · doi:10.7203/SCRIPTA.16.19235 
Jacob Mompó Navarro. Dona, pobra, mare i fadrina contra l'autoritat moral. El procés inquisitorial d'Àgueda Guimerà (1804)

Rey Castelao, O. (2015): «El trabajo de las mujeres rurales en la España Moderna. Un balance historiográfico», Revista de Historiografia, 22/1, pp. 183-210.

Rial García, S. (2008): «Una mirada a la evolución historiográfica de la historia de las mujeres», Sémata, 20, pp. 155-188.

Rial García, S. (2009): «Trabajo femenino y economía de subsistencia: el ejemplo de la Galicia moderna», Manuscrits: revista d'bistòria moderna, 27, pp. 77-99.

Sáez García, M. Á. (2018): «Las casas de arrepentidas y la clausura postridentina: la rebeldía femenina como forma de expresión disidente», Revista de Historia Moderna, 36, pp. 377-409.

Segura, I. (1996): «Espais de confinament: bordells i convents», Lectora: revista de dones i textualitat, 2 , pp. $77-81$.

Simón Hernández, F. (2017): «El estereotipo de la solterona: Literatura y constructión social en la Inglaterra de Jane Austen (1775-1817)», Revista de Historiografia, 26, pp. 125-148.

Torremocha, M. (2018): Cárcel de mujeres en el antiguo régimen. Teoría y realidad penitenciaria de las galeras, Madrid: Dykinson.

Tovar-Pulido, R. (2020): «Mujeres solteras e independientes en la España del siglo XVIII: rentas familiares y gestión patrimonial en el mediodía peninsular», Revista de Demografía Histórica, 38/1, pp. 149-178.

Turberville, A. (1954): La Inquisición española. Mèxic: Fondo de Cultura Económica.

Vidal Gadivia, M. A. (2000): La casa de arrepentidas de Valencia. Origen y trayectoria de una institución para mujeres, València: Consell Valencià de Cultura. 